элемента, его подкрепления и характеристик внешнего воздействия снарядов. Показано, что наиболее опасными случаями, учитывая защищенность сооружения, являются те, когда ударное действие повторяется через одинаковье промежутки времени, к тому же точки ударов находятся ближе к середине зашитного элемента. Полученнье теоретические результаты могут быть базой для выбора еще на стадии проектирования основных физикомеханических характеристик элементов инженерных сооружений и их подкрепления с иелью надежной зашить личного состава и техники максимально возможного воздействия на нее ударной серии снарядов. Достоверность полученных результатов подтверждается: а) обобщением иироко апробированных методик на новые классы динамических систем; б) получением в предельном случае известных в научных источниках последствий, касающихся линейно упругих характеристик элементов защитных сооружений; в) их непротиворечивостью сути самого физическому процессу, который рассматривается в работе.

Ключевые слова: инженерное сооружение, математическая модель действия системы взрывов, оиенка защитной способности.

\title{
ON WAYS TO INCREASE PROTECTION OF SPECIAL STRUCTURES FROM IMPACT ACTION
}

\author{
A. Andrukhiv, A. Baranov, N. Huzyk, B. Sokil, M. Sokil
}

The technique of research of dynamic processes of elements of engineering constructions of special purpose from explosive action of projectiles is developed. Elastically reinforced beams with hinged ends were chosen for the physical model of elements of engineering structures. It is assumed that the elastic properties of the latter satisfy the nonlinear technical law of elasticity. A mathematical model of the process of a series of impact actions of projectiles at different points of the element of the protective structure is constructed. The latter is a boundary value problem for a partial differential equation. Its peculiarity is that the external dynamic action is a discrete function of linear and time variables. To determine the dynamic effect of a series of impacts on the object under study, and thus the level of protection of the structure, the basic ideas of perturbation theory methods are extended to new classes of systems. This allowed to obtain an analytical dependence of the deformation of the elastically reinforced element on the basic physical and mechanical characteristics of the material of the protective element, its reinforcement and the characteristics of the external action of the projectiles. It is shown that the most dangerous cases, given the security of the structure, are those when the impact is repeated at equal intervals, in addition, the point of impact is closer to the middle of the protective element. The obtained theoretical results can be the basis for selection at the stage of designing the main physical and mechanical characteristics of the elements of engineering structures and their reinforcement in order to reliably protect personnel and equipment from the maximum possible impact on it of the shock series of projectiles. The reliability of the obtained results is confirmed by: a) generalization of widely tested methods to new classes of dynamical systems; b) obtaining in the limit case the consequences known in scientific sources concerning the linearly elastic characteristics of the elements of protective structures; c) their consistency with the essence of the physical process itself, which is considered in the work.

Keywords: engineering structure, mathematical model of action of the system of explosions, protection capability assessment.

UDK 62.505 .5

DOI: https://doi.org/10.33577/2312-4458.24.2021.57-63

S. Korolko, B. Seredyuk

Hetman Petro Sahaidachnyi National Army Academy, Lviv

\section{NANOMODIFIED RAPID HARDENING CONCRETES REINFORCED WITH DISPERSED BASALTIC FIBERS}

The article considers modern perspectives and directions of using fast - hardening high - strength concretes for protection against striking factors of action of different types of weapons. It is shown that the use of concrete materials in weapons and military equipment is one of the important components of defense structures and protective fortifications during hostilities as platoons and bases, and structures for the protection of civilians. The possibility of obtaining such concretes for the creation of special purpose fortifications is shown. Developed concrete structures have increased strength and impact resistance to high-speed impact. Due to the reinforcement of the concrete structure with mineral and chemical additives and ultrafine fibers, high rates of early strength, viscosity, crack resistance and impact resistance are achieved. The paper presents the main indicators of water consumption, strength and impact resistance of high-strength concrete. The results of the experimental study of samples of the destroyed concrete elements are presented and the corresponding conclusions concerning the use of various types of fibers for reinforcement of such concretes and increase of their crack resistance by basalt fibers are 
made. It is shown that a high-strength concrete with high construction and technical performance can be successfully used to create protective fortifications and fortifications for special purposes.

Keywords: modification, high-strength concrete, water consumption, concrete structures, impact strength, polycarboxylate plasticizer, high-speed impact.

\section{Formulation of the problem}

In a difficult military situation during the armed confrontation between Ukraine and the Russian aggressor, the use of protective materials and structures is an urgent task in the development and use of modern materials in armaments and military equipment. The Ukrainian experience is unique, as the war waged against us by Russia has no analogues in terms of the intensity of shelling, the use of equipment, modern weapons systems, intelligence and the use of new principles of hybrid warfare in the XXI century. This requires the implementation of appropriate innovative solutions and the use of modern special protective fortifications and structures. There is a need to develop standard design solutions for buildings and structures of increased security (in accordance with state standards "Design and maintenance of structural safety of buildings and structures in a terrorist threat"), development and implementation of universal protection systems, armor, mobile structures, fortifications, improvement existing and creation of new perspective solutions [1].

The protection of civilians both in the war zone and in areas at increased risk of capture required concrete action. Thus, in the period 2014-2015, the Ministry of Defense of Ukraine made a number of proposals that included effective actions in the field of civil protection of the population from the dangerous consequences of accidents and disasters of man-made, natural and military nature [1]. In particular, in the field of formation of new requirements for "civil protection" and the draft norms of DSTU B A.2.2-7: 2010, according to which separate decisions were made to inspect existing storage facilities for civil protection shelters, taking into account different degrees of impact and the arrangement of new storages and structures of special purpose with use of various materials and designs. Some scientific developments in this regard are carried out on the basis of the State program of creation and development of high-strength concretes and special purpose structures entitled "Fundamentals of technology for nanomodified fast-curing Portland cements and high-strength disperse-reinforced composites with high toughness based on them" (state registration number 0117U004446), which were performed by scientists of Lviv Polytechnic National University under the guidance of Doctor of Technical Sciences, Professor M.A. Sanytsky.
Modern armored protective materials must be characterized by high survivability, endurance, impact resistance. Among the many different protective materials and structures, concrete-based materials occupy a prominent place. Such concretes must be characterized by high strength, crack resistance and shock resistance properties.

It is known that ordinary concrete, even with significant compressive strength, is not able to provide high protective properties of concrete structures due to the increased fragility and heterogeneity of the concrete structure. In this regard, to obtain concrete protective structures there is a need for modern chemical and mineral modifiers, polymer additives and the use of the most possible potential resources of such concretes at the micro and nanoscale [2]. To ensure the required deformation resistance of such concrete structures, it is necessary to use reinforcing polymer, metal and natural fibers that provide the required crack resistance of concrete [3].

The use of concrete as a fortification, a variety of shelters, dugouts, hangars, open and closed firing positions from small arms, artillery and other weapons is possible thanks to its high mechanical properties, low penetration rate, emission resistance, and low ejection actions of bullets of different caliber [2].

One of the disadvantages of high-strength concrete is their low impact strength and increased sensitivity to cracking. The fragility of such concrete is primarily manifested by the reduction of plastic deformations due to various loads. At ultimate loads, such concrete collapses quite quickly and poses a risk of destruction due to excess design loads. During the operation and reliability of such structures there is a question of increasing the impact resistance of concrete and reducing resistance due to thermal fire and changes in temperature and humidity.

Concrete structures of fortifications perceive loads of multidirectional or concentrated action. Therefore, such concretes must have the maximum possible homogeneous component composition [3]. It should be noted that the stability of concrete is also associated with the action of the atmosphere, which can partially reduce its service life. Among the tasks often there is a need for rapid construction of such protective fortifications and structures and the need for rapid hardening of the concrete mixture. Therefore, there is a need to create and use fast-setting concrete with high early strength and the necessary construction and technical properties. 


\section{Analysis of recent research and publications}

Due to the use of modern innovative approaches based on the analysis of the processes of structure formation at the nanoscale, new potential opportunities for regulating the processes of hydration of the cement matrix open up. The potential of micro- and particles with sizes $(1-100) \cdot 10^{-9} \mathrm{~m}$ creates the possibility of maximum filling of the concrete matrix space and more or less uniform redistribution of particles $[4,10]$. In the range of micro- and nanosized hydrated particles, you can set the basic parameters and characteristics of the concrete matrix, which will further determine the basic properties of hardened concrete [2, 5, 10].

The creation of high-strength concrete protective shelters and structures is possible through the use of two main directions and strategies in construction. The first direction involves the introduction into the concrete mixture of synthesized nanoscale modifiers of different nature. First of all, these are active mineral additives, plasticizers and carbon nanomaterials. These include nanosilicon, shungite and carbon materials (carbon nanotubes and nanofibers) [5, 7]. The effect of modifying the crystal nuclei is provided by the uniform redistribution of nanosized crystallization centers (seeding effect).

Strengthening the contact between the cement stone and the aggregate allows to accelerate the process of gaining early strength of Portland cements [6]. The introduction of carbon materials of nanoscale composition, which are close to the thickness of the layers C-S-H phases of the cement matrix, makes it possible to record a significant change in the properties of the cement matrix in the early stages of hydration. However, a negative factor in the creation of such cement systems is the problem of homogeneous redistribution of nanomaterials due to the increased tendency to agglomeration. In addition, the synthesis of carbon nanomaterials is quite expensive and significantly affects the growth of the cost of manufacturing high-strength concrete in general [7].

A widely known technique in the technology of concrete production is their modification with polycarboxylate superplasticizers with a high effect of reducing water consumption and increasing the plasticity of concrete mixtures. The effect of polycarboxylate modifiers is due to the presence in their molecules of reactive hydrophobic radicals, which are able to increase the reaction component of the initial hydration of cement phases. As a result of the creation of adsorption layers, which inhibit the growth of crystals, the degree of wetting of dispersed particles increases [8, 9].

The implementation of nanotechnological approaches to the creation of high-tech fast-setting concretes is possible due to the mutual strengthening of the mineral and polymer components of the cement matrix and concrete in general. At the same time dispersion strengthening of system is provided and the possibility of relaxation of internal stresses is created. The analysis of perspective directions of control of crack formation of concrete systems shows that modification of structure of concrete by introduction of viscoplastic components and reinforcing dispersed fibers allows to compensate the increased fragility of concrete [3].

Artificial polypropylene, steel, or carbon fibers are widely used to obtain a high-strength dispersed reinforced concrete. However, when using high-density steel fiber, it is not possible to distribute them evenly in the concrete mixture [6]. This creates a protective layer of only one heavier layer and the distribution of steel fiber in different directions during loading will be uneven. In addition, the metal fiber due to the high surface hardness somewhat loses its ability to adhere to the cement matrix of concrete.

At the level of macrostructure, mineral or artificial fibers are highly effective, which have much better looseness and low weight. Therefore, it is important to use basalt fibers in such cement systems and create strong fast-setting concretes based on them.

The use of a nano-technological approach to create a homogeneous and stable structure of concrete and the formation of its strength and impact properties can be achieved through the introduction of nanodisperse mineral components, active superplasticizers of new generation and dispersed fibers that can be evenly distributed throughout the concrete matrix.

\section{Formulation of the purpose of the article}

To develop fast-hardening high-strength dispersed reinforcing concretes modified at nano-, micro- and mesostructural levels, as well as to investigate their properties, in particular in the conditions of high-speed impact for protective shelters and military structures.

For the production of high-strength high-strength concretes, Portland cement of general construction purpose of the HRC I-500 of PJSC "IvanoFrankivskcement" was used, which meets the requirements of DSTU BV 27-46: 2010, quartz sand of Zhovkva deposit with a size modulus of 2.2. Granite rubble with fractions from 5 to $20 \mathrm{~mm}$ was used as a filler. As a control sample, concrete of strength class $\mathrm{C}$ $32 / 40$ was used. The density and mobility of concrete mixtures were determined in accordance with the standard DSTU BV 2.7-114-2002. Active additives based on zeolite, microsilica and polycarboxylate plasticizers were used as additives to modify the concrete matrix.

Polypropylene, hydrophobic-modified and loose natural basalt fibers were used for reinforcement. As a result of the formation and hardening of concrete under 
normal conditions, five samples of concrete samples were obtained. Tests for compressive strength of concrete were performed in accordance with DSTU B B 2.7-214: 2009 after 2, 7 and 28 days of curing. 28 days after complete hydration in accordance with the requirements of the standards, the samples of the developed high-strength concretes were subjected to high-speed impact. To perform impact tests, concrete samples were fired from a distance of 5 meters from a gas pistol with spherical balls with a diameter of 3.0 $\mathrm{mm}$ and from a distance of $25 \mathrm{~m}$ using a conventional 5.45 caliber bullet from a Kalashnikov rifle single shots. The experiment was performed at the Yavoriv test site. A high-frequency (60 frames/sec) GoPro HERO 9 Black action camera with a slow-motion effect (sloumouschn) was used to study the effects of the destruction of standard-sized concrete blocks. Also, the study of samples of concrete samples at the macro level. The analysis was performed using an optical microscope with a resolution of $1.3 \mathrm{MPix}$ and a magnification of 500x.

\section{Presenting main material}

The use of building composites with active mineral components in modern construction is determined by the technological properties of the concrete mixture and the construction and technical properties of hardened concrete.

As a result of research it is established that the mobility of the concrete mixture of the control composition is characterized by the index of the cone draft $\mathrm{OK}=13 \mathrm{~cm}$ and meets the requirements of the standard for lightness P3. (Fig. 1, a), With the introduction of nanomodifiers and active mineral additives (composition № 2) provides a significant effect of modification of the concrete mixture. The mobility of the mixture increases to $\mathrm{OK}=24 \mathrm{~cm}$ (mark of lightness P5).

The use of reinforcing fibers based on polymeric polypropylene and basalt fibers causes some reduction in the mobility of the concrete mixture and an increase in the amount of water for wetting. In particular, the cone sediment of a concrete mixture with polypropylene fibers is reduced to $19 \mathrm{~cm}$, while mixtures with basalt fiber are reduced to $14 \mathrm{~cm}$, which is caused by a higher degree of dosing and hydrophilicity of the latter. The introduction of a complex organo-mineral modifier with the effect of plasticization causes an increase in the initial density of the system. The average density of dispersed-reinforced concrete mixtures increases to 2430-2480 kg / m3 (Fig. 1, b), which determines the effect of increasing the number of contacts between particles and accelerating the processes of structure formation.

According to the results of determining the strength at the design age, the concrete of the control composition corresponds to the strength class C 32/40 (Rst28 = 56.3 MPa). (Fig. 2). Modification of concrete with organo-mineral additives and plasticizers provides an increase in its strength at an early age.
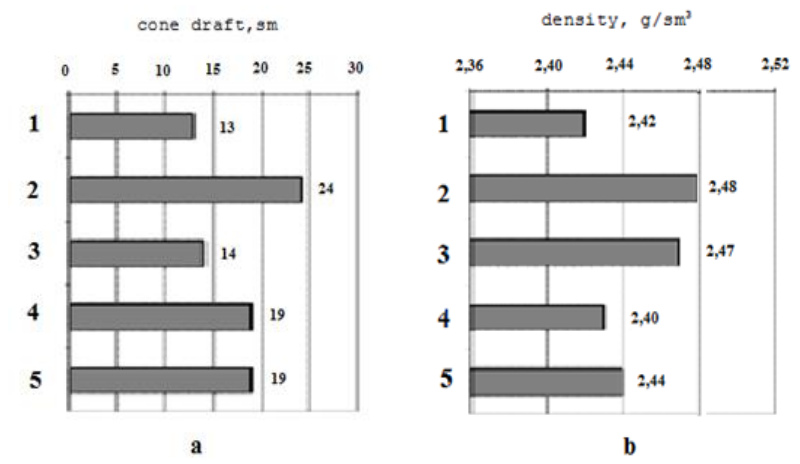

Fig. 1. Mobility (a) and average density (b) of concrete mixtures

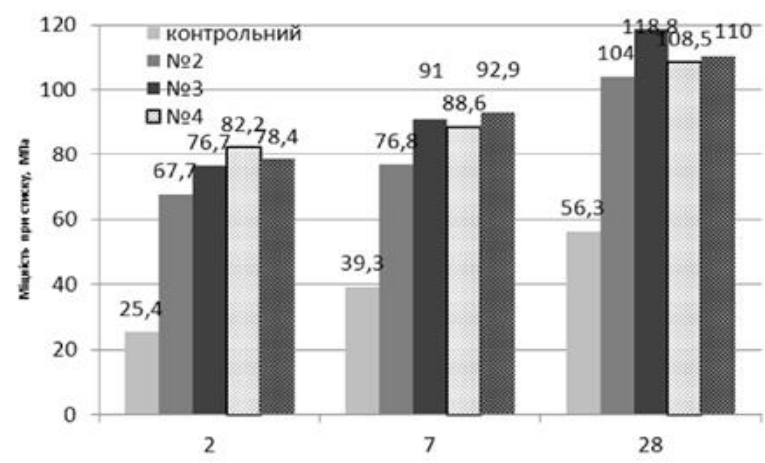

Fig. 2. Strength of disperse-reinforced high-strength concrete

In particular, the strength of nanomodified concrete without fiber (composition № 2) after 2 days of hardening is $67.7 \mathrm{MPa}$, which is 2.7 times higher than the strength of concrete of the control composition. The compressive strength of such concrete at the design age corresponds to the strength class $C 65 / 75$.

With dispersed reinforcement, the strength of concrete after 2 days increases by $13-21 \%$ compared to non-reinforced. The strength after 28 days is 108.6118.8 $\mathrm{MPa}$, which corresponds to class $\mathrm{C} 70 / 85$. When reinforcing with synthetic fiber, the coefficient of structural quality of nanomodified fast-setting fibroconcretes increases to 44.8-49.1 MPa compared to 23.4 MPa for control concrete.

During the tests of concrete for impact resistance using a gas gun and spherical balls of low weight and low initial velocity, concrete cubes of standard size were practically not destroyed. As a result of the shelling, some surface damage to the concrete matrix can be recorded only on the control sample.

On other samples of samples of high-strength modified concrete only traces of defeat are visible. The depth of destruction of the samples does not exceed $0.5 \mathrm{~mm}$. In contrast to these concrete samples in the control 
sample we observe deeper surface lesions up to $2 \mathrm{~mm}$. (Fig. 3, a, b).

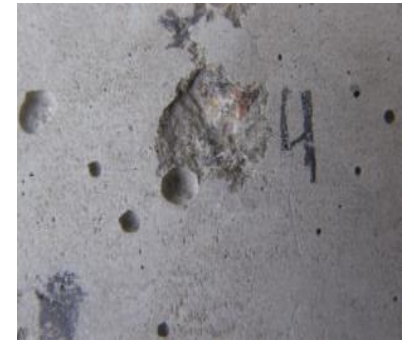

a)

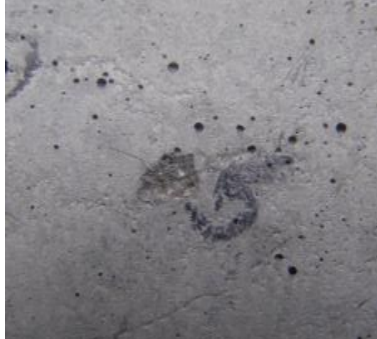

б)

Fig. 3. General view (a) and average density (b) of concrete mixtures

In this case, it is difficult to compare samples of samples № 2-5. In this regard, the impact resistance of high-strength concrete was studied at the Yavoriv test site using a conventional 5.45 caliber bullet. During the tests of concrete samples, single shots were recorded by single video footage, which indicate significant destruction of the concrete matrix of the base composition (Fig. 4).

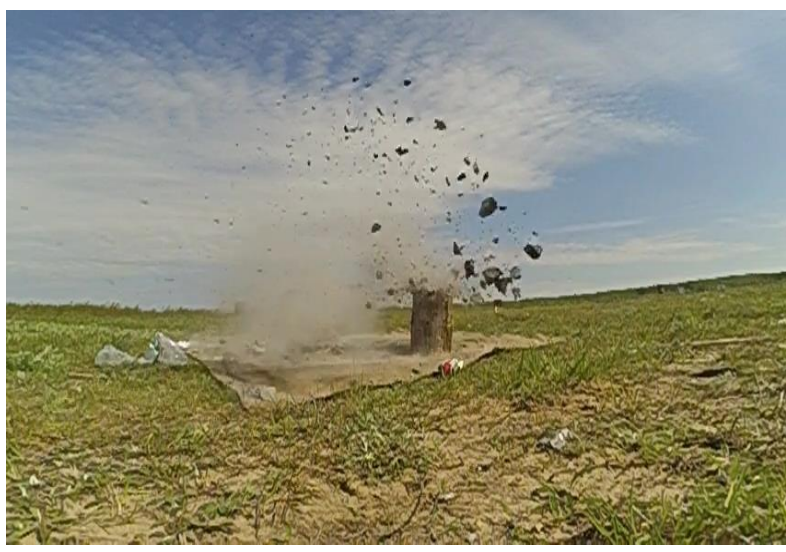

Fig. 4. Fragment of destruction of concrete of base composition with strength class $\mathrm{C} \mathrm{32/40}$

The concrete cube collapses almost completely to obtain a significant number of fragments. After tests on the effect of high-speed impact, the cubes of the control composition of concrete, in addition to the chipped particles, contain significant defects throughout the volume of the cube with a grid of cracks (Fig. 5, a).
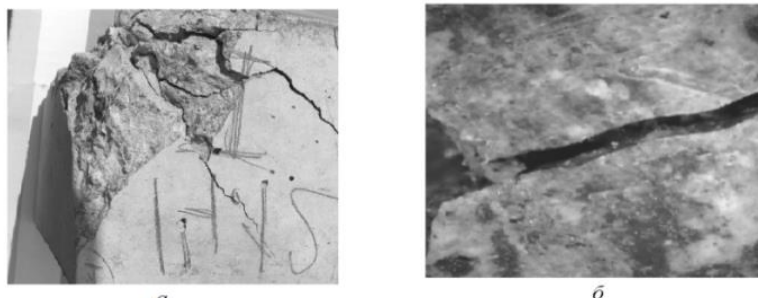

Fig. 5. General view (a) and microstructure $(x 50)$ of the surface (b) of the cube samples concrete control composition after high-speed impact tests
The destruction of concrete took place along the surface of the contact zone between the cement matrix and the aggregate. The crushed stone remained virtually intact, which indicates its weak interaction with the cement matrix. Microstructural analysis of concrete samples confirms the presence of deep cracks with a width of more than $5 \mathrm{~mm}$ (Fig. 5, b).

Samples of nanomodified high-strength concrete with dispersed fibers after the action of high-speed impact (sample № 4) are characterized by individual chipped particles, which is caused by a concentrated impact of the bullet. The destructive load from axial compression and bending took place in three main directions of the cubic sample. Cracks on the surface of the intact part of the cube are almost absent (Fig. 6). It should be noted that the chipping of individual particles of the structure was not on the contact surface of the cementitious matrix and the coarse aggregate, and on the plane of greatest impact load. The grains of crushed stone were destroyed in the direction of force. This indicates the point destruction of the nanomodified concrete matrix. The base of the cube remained solid and virtually intact. Microscopic studies of the surface of samples of high-strength fast-setting concrete reinforced with basalt fiber indicate a homogeneous structure of the hardened cementitious matrix. Strengthening the contact of the interaction between the cement stone and the aggregate and the use of basalt reinforcing fibers, which are evenly distributed in the cement matrix (Fig. 6) indicates the effectiveness of the composite under the action of shock loads.

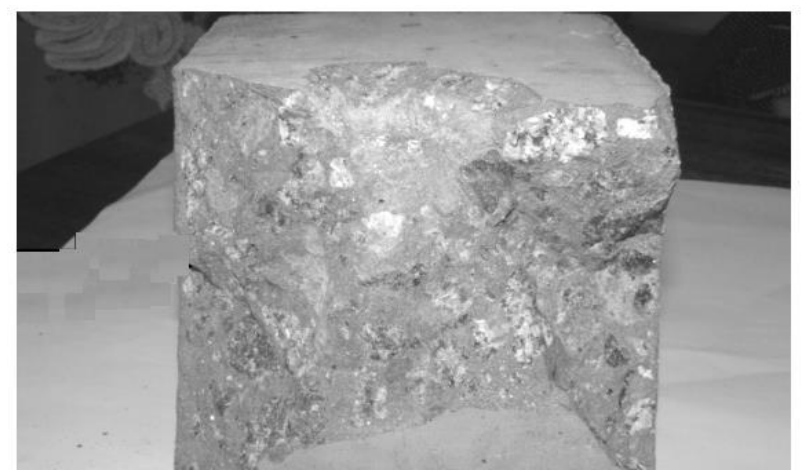

Fig. 6. General composition concrete view (a)

Conclusion. Modification of the cement matrix in concretes with organo-mineral additives, containing ultrafine mineral components, fillers, polycarboxylate superplasticizers and natural basalt fibers, provides strong fast-setting concretes with increased impact strength, crack resistance and compressive strength.

Achieving high strength of concrete and increased impact resistance are ensured by increasing the density of the cementitious matrix as a result of optimizing the grain composition, reducing water consumption and the use of basalt fibers. Separate tests of high-strength modified concretes reinforced with fibers of different 
nature for impact resistance in the landfill conditions and their construction and technical properties were determined. Obtaining nanomodified high-strength structural concrete of the new generation for the construction of fortifications and shelters with a high level of crack resistance, resistance to various types of force, including shock loads opens up new potential opportunities for the use of such materials for the protection of personnel of units of the Armed Forces of Ukraine and civil protection of the population.

\section{References}

1. Bilyk A.S., Picul A.V., Nuznyj V.V. and Schajduk M.V. (2016), "Kafedra metalevych i derevjanych konstrukcij KNUBA dlja zachystu batkivschchyny" [Department of metal and wooden structures KNUBA to protect the homeland].

Urban planning and spatial planning: Scientific and technical collection Lviv. Issue № 61. pp. 33-44. DOI: http://library.knuba.edu.ua/books/zbirniki/02/2016/201661.pdf [in Ukrainian].

2. U. Marushchak, M. Sanytsky, S. Korolko, Yu. Shabatura and N. Sydor. (2018), Development of nanomodified rapid hardening fiber-reinforced concretes for special-purpose facilities. Eastern-European journal of enterprise technologies, 2018, Volume 2/6 (92): pp. 34-41. (SCOPUS). DOI: https://doi.org/10.15587/1729-4061.2018.127001

3. Korolko S.V., Martynjuk I.M., Stadnichuk O.M. and Horczynskyj I.V. (2018), "Perspektyvy vykorystannia bazaltovykh fibrobetoniv dlia fortyfikatsiinykh sporud" [Prospects for the use of basalt fiber concrete for fortifications]. Military-technical collection. Lviv. Issue № 19. pp. 66-72. DOI: $\quad$ https://doi.org/10.33577/23124458.19.2018.66-72 [in Ukrainian].

4. Aaron Richard Sakulich and Victor C. Li (2011), Nanoscale characterization of engineered cementitious composites (ECC). Cement and Concrete Research. Volume 41. Issue 2. pp. 169175. DOI: https://doi.org/10.1016/j.cemconres.2010.11.001 5. Jo B.-W., Kim C.-H., Tae G. and Park J.-B. (2007), Characteristics of cement mortar with nano- $\mathrm{SiO}_{2}$ particles, Construction and Building Materials, No. 21, pp. 1351-1355. DOI:

https://hanyang.elsevierpure.com/en/publications/characteristi cs-of-cement-mortar-with-nano-siosub2sub-particles

6. Konsta-Gdoutos M.S., Metaxa Z.S. and Shah S.P. Highly dispersed carbon nanotube reinforced cement based materials, Cement and Concrete Research, Vol. 40, Issue 7, 2010, pp. $1052-1059$

DOI https://www.sciencedirect.com/science/article/abs/pii/S000888 4610000542

7. Tolmachev S.N. and Belichenko E.A. (2014), "Primenenie uglerodnych kolloidnych nanochastits $v$ melkozernistych tsementnych betonach" [The Application of carbon colloidal nanoparticles in fine-grained cement concretes]. Monograph Kharkov, KhNADU Publ., 2014, 152 p. [in Russian].

8. Plank J., Schroefl C. and Gruber M. (2009), Effectiveness of polycarboxylate superplasticizers in ultra-high strength concrete. Journal of Advanced Concrete Technology. Vol. 7. № 1. 2009. pp. 5-12. DOI: https://doi.org/10.3151/jact.1.215 9. Marushchak U., Sanytsky M., Mazurak T. and Olevych Yu. (2016), Research of nanomodified Portland cement compositions with high early age strength. Eastern-European
Journal of Enterprise Technologies. Vol. 6/6 (84). pp. 50-57. DOI: https://doi.org/10.15587/1729-4061.2016.84175

10. Marushchak U., Sanytsky M. and Korolko S. (2017), "Nanomodyfikovani schvydkotverdnuchi betony, armovani dyspersnymy voloknamy" [Nanomodified rapid hardening Fiber reinforced concretes]. Visnyk «Theory and practice of construction» NU “Lvivska Polstechnika”, Lviv. Issue № 877, pp. 137-143. DOI: http://ena.lp.edu.ua:8080/handle/ntb/44189 [in Ukrainian].

\section{Список літератури}

1. Білик А. С., Пікуль А. В., Нужний В. В., Шайдюк М. В. Кафедра металевих і дерев'яних конструкцій КНУБА для захисту батьківщини. Містобудування та територіальне планування : наук.-техн. збірник / під. ред. М. М. Осєтріна. Київ, КНУБА, 2016. Вип. 61. С. 33-44. ОI: http://library.knuba.edu.ua/books/zbirniki/02/2016/201661.pdf 2. U. Marushchak, M. Sanytsky, S. Korolko, Yu. Shabatura, N. Sydor. (2018), Development of nanomodified rapid hardening fiber-reinforced concretes for special-purpose facilities. EasternEuropean journal of enterprise technologies, 2018, Volume 2/6 (92): pp. 34-41. (SCOPUS). DOI: https://doi.org/10.15587/1729-4061.2018.127001

3. Королько С. В., Мартинюк I. М., Стаднічук О. М., Горчинський I. В. Перспективи використання базальтових фібробетонів для фортифікаційних споруд. Військовотехнічний збірник. Львів, 2018. № 19. С. 66-72. DOI: https://doi.org/10.33577/2312-4458.19.2018.66-72

4. Aaron Richard Sakulich, Victor C. Li (2011), Nanoscale characterization of engineered cementitious composites (ECC). Cement and Concrete Research. Volume 41. Issue 2. pp. 169175. DOI: https://doi.org/10.1016/j.cemconres.2010.11.001

5. Jo B.-W., Kim C.-H., Tae G., Park J.-B. (2007), Characteristics of cement mortar with nano- $\mathrm{SiO}_{2}$ particles, Construction and Building Materials, No. 21, pp. 1351-1355. DOI:

https://hanyang.elsevierpure.com/en/publications/characteristi cs-of-cement-mortar-with-nano-siosub2sub-particles

6. Konsta-Gdoutos M.S., Metaxa Z.S., Shah S.P. Highly dispersed carbon nanotube reinforced cement based materials, Cement and Concrete Research, Vol. 40, Issue 7, 2010, pp. 1052-1059.

DOI:

https://www.sciencedirect.com/science/article/abs/pii/S000888 $\underline{4610000542}$

7. Толмачев С. Н., Беличенко Е. А. Применение углеродных коллоидных наночастиц в мелкозернистых цементных бетонах : монография. Харьков, Изд-во: ХНАДУ, 2014. 152 c. DОI: https://scholar.google.com.ua /citations?user=iCsBtAUAAAAJ\&hl=ru

8. Plank J., Schroefl C., Gruber M. Effectiveness of polycarboxylate superplasticizers in ultra-high strength concrete. Journal of Advanced Concrete Technology. Vol.7. № 1. 2009. P. 5-12. DOI: https://doi.org/10.3151/jact.1.215

9. Marushchak U., Sanytsky M., Mazurak T., Olevych Yu. Research of nanomodified Portland cement compositions with high early age strength. Eastern-European Journal of Enterprise Technologies. 2016. Vol. 6/6 (84). pp. 50-57. DOI: https://doi.org/10.15587/1729-4061.2016.84175

10. Марущак У., Саницький М., Королько С. Наномодифіковані швидкотверднучі бетони, армовані дисперсними волокнами. Вісник "Теорія і практика будівниитва". НУ «Львівська політехніка». Львів, 2017. № 877. С. $137-$ 143. DOI: http://ena.lp.edu.ua:8080/handle/ntb/44189 
Наномодифіковані високоміцні бетони, армовані дисперсними базальтовими волокнами

\section{С.В. Королько, Б.О. Середюк}

У статті розглянуто сучасні перспективи та напрями використання швидкотверднучих високоміцних бетонів для захисту від уражаючих факторів дії різних видів зброї. Показано, щьо використання бетонних матеріалів в озброєнні та військовій технічі є одним із важливих компонентів оборонних конструкцій та захисних укріплень, під час бойових дій, для взводів та опорних пунктів, так і споруд для захисту цивільного населення. В статті показано, щцо застосування армуючих волокон на основі полімерного поліпропілену та базальтових волокон спричиняє деяке зменшення рухливості бетонної суміші та збільшення кількості води замішування. Підтвердженням иього є збільшена густина затверділого бетону. Введення комплексного органо-мінерального модифікатора з ефектом пластифікаиіі спричинює збільшення густини бетонної сумімі. Це свідчить про збільшення кількості контактів між частинками та прискорення прочесів структуроутворення. Показано, щя протягом двох днів міиність наномодифікованого бетону без волокна в 2,7 рази перевищує міцність бетону контрольного складу. В проектному періоді міцність на стиск такого бетону відповідає класу мічності С 65/75. Завдяки армуванню структури бетону мінеральними і хімічними добавками та ультрадисперсними волокнами досягаються високі показники ранньої міиності, в'язкості, тріщиностійкості та протиударного ефекту. Розроблені бетонні конструкції мають підвищенні показники міцності та протиударноі стійкості до дії високошвидкісного удару. Показано результати експериментальних досліджень зразків зруйнованих бетонних елементів та зроблено відповідні висновки щодо використання різних типів волокон для армування таких бетонів та підвищення їх тріщиностійкості поліпропіленовими та базальтовими волокнами. Найвищі показники тріщиностійкості та ударної міиності розробленого бетону досягаються з використанням модифікованих базальтових волокон. Використання високоміцних бетонів з підвищеними будівельно-технічними показниками можуть успішно використовуватись для створення захисних укріплень та фортифікаційних споруд спеціального призначення.

Ключові слова: модифікування, високоміџний бетон, водопотреба, бетонні конструкції, ударна в'язкість, полікарбоксилатний пластифікатор, високошвидкісний удар.

\section{Наномодифицированные высокопрочные бетоны, армированные дисперсными базальтовыми волокнами}

\section{С.В. Королько, Б.О. Середюк}

В статье рассмотрены современные перспективы и направления использования быстротвердеюших высокопрочных бетонов для защиты от поражающих факторов воздействия различных видов оружия. Показано, что использование бетонных материалов в вооружении и военной технике является одним из важных компонентов оборонных конструкиий и защчитных укреплений, как во время боевых действий, для взводов и опорных пунктов, так и сооружений для защчиты гражданского населения. В статье показано, что применение армируюших волокон на основе полимерного полипропилена и базальтовых волокон вызывает некоторое уменьшение подвижности бетонной смеси и увеличение количества воды замешивания. Подтверждением этого является увеличенная плотность затвердевиего бетона. Введение комплексного органо-минерального модификатора с эффектом пластификации вызывает увеличение плотности бетонной смеси. Это свидетельствует об увеличении количества контактов между частицами и ускорения процессов структурообразования. Показано, что в течение двух дней прочность наномодифицированного бетона без волокна в 2,7 раза превышает прочность бетона контрольного состава. В проектном периоде прочность на сжатие такого бетона соответствует классу прочности C 65/75. Благодаря армированию структурь бетона минеральными и химическими добавками и ультрадисперсными волокнами достигаются высокие показатели ранней прочности, вязкости, трещциностойкости и противоударного эффекта. Разработанные бетонные конструкции обладают повышенными показателями прочности и противоударной стойкости к воздействию высокоскоростного удара. Показаны результаты экспериментальных исследований образиов разрушенных бетонных элементов и сделаны соответствуюшие выводы по использованию различных типов волокон для армирования таких бетонов и повылиения их трещиностойкости полипропиленовыми и базальтовыми волокнами. Самые высокие показатели трещиностойкости и ударной прочности разработанного бетона достигаются с использованием модифицированных базальтовых волокон. Использование высокопрочных бетонов с повышенными строительно-техническим показателями могут успешно использоваться для создания защцитных укреплений и фортификационных сооружений специального назначения.

Ключевые слова: модифицирование, высокопрочный бетон, водопотребность, бетонные конструкции, ударная вязкость, поликарбоксилатный пластификатор, высокоскоростной удар. 